\title{
The role of diosgenin in crohn's disease
}

\author{
Sunday Ogundepo ${ }^{1}$, Adinnu M. Chiamaka², Mercy Olatinwo', David Adepoju', Matthias Taiwo Aladesanmi', \\ Ugwu Obiora Celestine ${ }^{4}$, Kingsley Chijioke Ali ${ }^{5}$, Ogochukwu Jennifer Umezinwa ${ }^{6}$, Janet Olasore ${ }^{1}$ and \\ Abdullahi Alausa ${ }^{1 *}$ (D)
}

\begin{abstract}
Inflammatory bowel disease (IBD) is a chronic idiopathic inflammation that can grossly affect the entire gastrointestinal tract (GIT) from the mouth to the anus. Crohn's disease is the most known type of IBD and has been the focus of attention due to its increase in prevalence worldwide. Although the etiology is yet to be elucidated, recent studies have pointed out Crohn's disease to arise from a complex interaction between environmental influences, genetic predisposition, and altered gut microbiota, resulting in dysregulated adaptive and innate responses. The presenting hallmarks of Crohn's disease may include weight loss, nausea, vomiting, abdominal pain, diarrhea, fever, or chills. Treatment is usually done with many approved immunosuppressive drugs and surgery. However, a promising avenue from natural compounds is a safer therapy due to its safe natural active ingredients and the strong activity it shows in the treatment and management of diseases. Diosgenin, "a major biologically active natural steroidal sapogenin found in Chinese yam," has been widely reported as a therapeutic agent in the treatment of various classes of disorders such as hyperlipidemia, inflammation, diabetes, cancer, infection, and immunoregulation. In this review, an analysis of literature data on diosgenin employed as a therapeutic agent for the treatment of Crohn's disease is approached, to strengthen the scientific database and curtail the dreadful impact of Crohn's disease.
\end{abstract}

Keywords: Crohn's disease, Diosgenin, Inflammation, STAT3, NF-KB activity

\section{Introduction}

Crohn's disease is an enervating and incorrigible persistent inflammatory bowel disease (IBD). Four years ago, over six million cases of IBD were reported globally with a reported increase in age prevalence rate from 79.5-84.3\% per a hundred thousand population [1]. High Socio- demographic Index (SDI) locations revealed the highest amount of age-standardized prevalence rate ranging from USA (most prevalent) to Singapore (least prevalent). It is portrayed by mucosal inflammatory ulceration, which could grow along the gastrointestinal tract (GIT) yet most normally influence the distal small digestive system. IBD is characterized by inflammation of the transmural, affecting the thickness of the

\footnotetext{
*Correspondence: alausaopeyemi0@gmail.com

${ }^{1}$ Department of Biochemistry, Faculty of Basic Medical Sciences, Ladoke

Akintola University of Technology, Ogbomosho, Oyo State, Nigeria

Full list of author information is available at the end of the article
}

entrail wall [2]. While the pathogenesis of Crohn's disease (CD) is somewhat complex, it is imperative to note that the site of disease onset is activated by natural factors which derange the mucosal barriers, thus modulating the healthy stasis of the gut microbiota.

These principal factors (immune response, microbiota, and genetics) are affected by the individual's exposure which relates to other risk factors leading to Crohn's disease [3]. Modern treatment in Crohn's disease includes the use of immunomodulators (thiopurines and methotrexate), anti-inflammatory agents (corticosteroids), anti-tumor necrosis factor agents (anti-TNF), antibiotics, as well as surgical processes $[4,5]$. A study showed that the usage of anti-TNF agents and thiopurines gave synergistic result that were effective in the management of Crohn's disease by about 50\% [6]. However, Chinese yam (Dioscorea opposita), a regional crop in China [7] is of nourishing and fiscal importance. It is grown in the northeastern, central, and southeastern areas in China 
having Henan province as the major growing region of Dioscorea species with the highest grade. The nutrients present in Chinese yam includes proteins with $(3.59 \%$ $8.93 \%)$, starches $(43.7 \%)$, amino acids $(2.31 \%$ to $7.26 \%)$, sugars (3.39\%), vitamins and amylases [8-10]. While diosgenin is inarguably the most potent phytochemical in Dioscorea spp [11, 12], allantoin which is known to assist in wound healing, and speed up cell regeneration is also present in bountiful quantities in Dioscorea spp [13]. However, a steroidal saponin, particularly diosgenin is the exemplary phytochemical in Dioscoreaceae $[11,12]$.

Diosgenin denotes a C27 spiroketal steroidal saponin richly accessible in nature. Saponin, an active compound in plants like Trigonella, Costus, and Smilax species is found in Dioscorea opposita [14-16]. This steroid represents a great significance to industries and has been a subject important to numerous scientists worldwide throughout the years. Moreover, the therapeutically helpful steroidal medications, such as corticosteroids and sex hormones are derived in a semisynthetic manner from its active precursor diosgenin [17, 18]. Recently, studies reported that diosgenin possesses numerous biological activities such as hypolipidemic, anti-inflammatory, anti-proliferative, hypoglycemic activity, as well as a potent antioxidant [19-21]. However, further research have shown that diosgenin exhibits an immunosuppressive effect in inflammatory bowel disease via inhibition of NF- $\mathrm{KB}$ activity [22-26]. Taking into account that Crohn's disease is a chronic relapsing inflammatory disease, this review is aimed at illustrating the complex role of NF- $\mathrm{KB}$ activity and suggesting the active constituents present in Chinese yam (diosgenin) as a therapeutic agent for the management of Crohn's disease. This review futher detailed the pathogenesis of Crohn's disease and as well explain the pharmacological role of diosgenin in the management of this disease.

\section{Pathogenesis of CROHN'S disease}

Over the years, the outbreak of Crohn's disease has been recorded in several continents, particularly in Northern and Western Europe, also in North America regions [27]; $0.21 \%$ per year in North America, $0.16 \%$ per year in the United Kingdom and 0.09\% per year in Northern Europe [28-33]. Minor cases are reported in Africa, South America, and Asia [27]. Study reports from epidemiologists revealed that women are even more susceptible to Crohn's disease than men and it is more common among individuals of Ashkenazi Jews [27].

Crohn's disease is associated with an imbalance in any part of the GIT contrary to ulcerative colitis, affecting the colon alone. However, the manifestation of this disease exhibited some certain diseases such as; ileocaecal disease $(40 \%)$, ileal disease (30\%), or colonic disease (25\%).
There is the presence of anorectal abscess virtually in 30\% of patients with this disease. Anatomical studies denoted Crohn's disease to be sporadic, leading to damages in the intestine ("skip" lesions), and the bowel infected with edematous and the accumulation of fat deposit on the serosal surface. Finally, there is the formation of Ulcer in the mucous membrane altering dispersed aphthous ulcers to profound serpiginous pleomorphic ulcers. These can delve into the intestines, resulting in the formation of a fistula between the infected intestines with the contiguous intestines, bladder, vagina, or skin [34].

Although the etiology of Crohn's disease is yet to be elucidated, recent studies from researches have proposed several mechanisms which suggest CD may result from genetic susceptibility, environmental factors, and intestinal microflora, leading to an aberrant immune response with a pact epithelial barrier function [35].

\section{Genetics}

Genetic studies on twins and families attested an active genetic impact on the procurement of $\mathrm{CD}$. For instance, it was confirmed in about $50 \%$ of monozygotic twins together with $30 \%$ of offspring of parents affected with CD [36]. The successful genome-wide association (GWA) studies with linkage analysis and positional cloning program have analyzed over 30 specific genetic loci that brought major insight to CD etiology. Some of the most strongly related gene susceptible to the role $\mathrm{CD}$ pathogenesis includes (CARD15/NOD2, IRGM, IL23R, LRRK2, and ATG16L1), interleukin 23 (IL-23) and T helper 17 (Th17), cell pathway (IL23R, IL12B (encoding IL-12p40), STAT3, JAK2, and TYK2) [37, 38].

The first gene discovered, Nucleotide-binding oligomerization domain-containing protein 2 (NOD2) locus on chromosome 16q12 [39-41], is a cytosolic recognition receptor modulating the immune system against intracellular bacteria. However, $40 \%$ of western patients affected with CD exhibited three variations ((amino-acid substitutions Arg702Trp, Gly908Arg, and the frameshift FS1007insC) in the gene located within the leucine-rich repeat domain subjected for sensing muramyl dipeptide (MDP), a peptidoglycan component of both gram-positive and gram-negative bacteria cell wall [42]. NOD2 is expressed in diverse roles relating to several cellular processes including regulating panteth cell function, viral sensing, altering apoptosis in regulating $\mathrm{T}$ cell, and regulating autophagy [41]. Studies have revealed that defects in NOD2 expression affect the sensing of muramyl dipeptide which activates series of innate immune responses and bacteria-killing, leading to the tenacity of intracellular bacteria with an effect on antimicrobial role in the lumen [43-45]. In continuation, MDP activation resulted in regulating effects of inherent immune 
system such as suppressing cytokine effects (IL-23 driven Th17 responses), repression of other protein recognition receptor (TLR-2 and TLR-4 responses) and initiation of tolerance (via IL-10 and decreased TGF- $\beta$ ) [46, 47]. In addition, the activation of MDP via NOD2, induces the recruitment of the Ser/Thr/Tyr kinase RIPK2, which is a significant approach to downstream signaling pathways activation which stimulate the activation of NF- $\mathrm{KB}$ signaling pathways and MAPK, modulating the production of effector molecules such as IL-8 [48-51]. IL-8, also known as neutrophil chemo-attractant denoting a pleiotropic proinflammatory cytokine developed from different stressors [52], also can be distinguished as an effective angiogenic factor relating to tumor growth and metastatic tumor [53,54] and as biomarkers for many chronic inflammatory diseases [55-57]. As regards NOD2, it was revealed that several cellular components secretes IL-8 in response to the activation of NOD2 [58], with many groups which depict a decrease in IL-8 secretion in cells of CD patients due to NOD2 polymorphism $[59,60]$. Furthermore, on the gene susceptible to the role of $C D$, the detection in polymorphism of autophagy gene (ATG161, LRRK2, and IRGM) from GWAs in CD has activated important research work in IBD. Autophagy has been studied to play a crucial role in organism on cellular survival, differentiation, development and homeostasis against various pathologies such as infections, cancer, neurodegeneration and aging [61]. Studies on ATG161L1 genes gave clear discernment on pathogenic results. However, two recent studies have revealed the defective autophagy response towards bacteria in the induction of CD. Cooney et al., (2010) revealed autophagy relations with NOD2; In reaction to MDP, autophagy is induced via receptor-interacting serine/threonine -protein kinase 2 (RIPK2), ATG7, ATG5 and ATG16L1 in dendritic cells. This reaction triggered the handling of bacteria through direct engulfment and successive propagation of major histocompatibility complex (MHC) class11 for antigenspecific CD4+ T-cells responses in DCs [45]. Travassos et al., (2010) have also showed NOD2 to raise ATG16L1 to the plasmalemma at the entry point of bacteria to trigger xenophagy [62].

\section{Environmental factors}

Among the environmental factors hypothesized in CD, cigarette smoking has been found to be the most prominent epidemiology evidence in the pathogenesis of $\mathrm{CD}$. It was revealed that smokers are likely to develop $C D$ with a two-times increase compare to non-smokers [18-20] [63]. A study has revealed that the effect of cigarette smoking can cause severe damages to both innate and adaptive immune responses, causing increase to microbial infection which would aid its role in the etiology of
CD [64]. Over the past decade, the role of environmental and genetic factors has been the major research contributed to the etiology of $\mathrm{CD}$. Also, it has been proven that extract from cigarette smoke could cause a setback in NOD2 mRNA expression leading to the deterioration of NOD2 activity in intestinal epithelial cells [65].

In addition, the impact of diet seems ambiguous in developing $\mathrm{CD}$. However, certain studies have illustrated diet containing excessive number of sugars, omega- 6 fatty acids, polyunsaturated fatty acids, total fat and meat increases the risk of developing $\mathrm{CD}$ but a diet rich in fiber and fruits lessened the growth of CD [66-68]. Also, the usage of non-steroidal anti-inflammatory drugs, aspirin, antibiotics, oral contraceptives and antibiotics are all connected with increasing the risk of CD [69-73].

Finally, the effect of epithelial differentiation and gutrelated lymphoid tissue assembly in innate intestinal microbiota have been hypothesized to be involved in the pathogenesis of CD [74], changes in the disintegration of intestinal mucosa or modification in the gut microbiome appears to activate the growth of CD in the bowel [75]. The interface between the gut microbes and host T-cells is an epithelial layer. The secretion of host protective factors like defensins, and the surface mucus layer, as well as the autonomic nervous system and the basement membrane and the integrity of the epithelial cell influences the epithelial permeability. However, certain bacterial strains gravitate the change in bowel permeability in animal models, this alteration triggers an abnormal immune response showing increase in epithelial permeability in $C D$ patients [76]. Patient affected with $C D$ frequently show dysbiosis which includes increase in Gramma proteobacteria and Actinobacteria as well as decrease in Bacteriodes and Firmicutes bacteria [77].

\section{Immunological factors}

$\mathrm{CD}^{+}$/ T-helper cells, a key regulator in the immune system can be classified as Th1, Th17, Foxp $3^{+}$regulatory $\mathrm{T}$ (Treg) cells [78]. In some patients with $\mathrm{CD}$, there is overproduction of cytokines such as interleukin 12(IL12) and interferon $\gamma$ (IFN- $\gamma$ ) from the mucosal dendritic cells and macrophages leading to Th1 differentiation and inflammation within the intestinal mucosa [79]. High level of activated STAT4 and T-bet, IL-12 (Th1-assoicated transcriptional factor) was present in a nuclear extract from T-cells confined from inflamed Crohn's disease lesions [80]. Also, an embellished production of IL-18, a cytokine involved in perpetuating Th1 cells responses was revealed in the mucosa of patient with $\mathrm{CD}$ $[81,82]$. Furthermore, in the membrane of patients with $\mathrm{CD}$, there is abundant secretion of IFN- $\gamma$ lamina propria lymphocytes which appears to escalate a classic Th1 response resembling an acute infection process [83]. 
Several studies have been demonstrated on the role of Th17 cells in animals relating to gut inflammation and autoimmunity, of which there are few studies being examined on the effect of Th17 cells in patient with $C D$. A recent study in the lamina propria of patients with CD depicted an increased number of T-cells expressing retinoid-related orphan receptor $-\gamma+(\mathrm{ROR} \gamma+)$, the great transcriptional factor for Th17 cells [84]. Pene et al. in their study isolated Th17 cells from deteriorated lesions of patient with Crohn's disease [85]. Furthermore, in both human peripheral blood and the gut from healthy individual as well as patients with $C D$, two autonomic studies were proved on Th17 cells $[86,87]$. The Th17 designated cytokines (IL-17A, IL-17F, IL-22, and IL-26) are increased in the bowel and serum of patient with IBD, and Th17 cells having a stimulated phenotype shown in the intestinal mucosa and blood of patients affected with CD [88-91]. Moreover, the two studies depicted these cells in the expression of ROR- $\gamma+$, IL23R and CCR6, lacking CXCR3, a chemokine receptor designated for Th1 cells [86, 87]. Annunziato et al. in their study indicated IL-17A-producing T-cells in the intestine, with T-cells populations showing the expression of both IL-17A and IFN- $\gamma$, denoted as "Th17/Th1" cells [86]. Acosta-Rodriguez et al. also determined Th17 cells to give the expression of CCR6+ CCR4+, as well as CCR6 + CXCR3+ expressing Th1 cells to produce both IL-17A and IFN- $\gamma$ [87].

Treg cells, which are expressed by Forkhead box P3 (FOXP3) are stable descent of dedicated regulator cells which play role in suppressing immune responses and perpetuation of relative constant condition within organism through resistance to self-antigens [92]. The operation of $\mathrm{CD} 4^{+}, \mathrm{CD} 25^{+}$and sparse expression of CD127(IL-7 receptor) have been denoted to be the typical features of Tregs. In addition, the intolerance between the activated Treg cells as well as activated CD4 ${ }^{+}$T-cells is an expression of FOXP3, indicated as an explicit molecular marker [93]. FOXP3 regulatory roles are delineated in cell-cell interaction and the production of cytokines such as IL-10, IL-35 and TGF- $\beta$. However, genetic variants of IL-10 and IL-35 with autoimmune disease conveys a recommendation in the etiology of IBD [94, 95]. Interestingly enough, studies on the impaired role of IL-10 receptor in human due to mutation have been delineated in a thorough clinical manifestation of CD [96]. Furthermore, studies have revealed that the upregulation of T-cells specific T-box transcription factor (T-bet), STAT, and the nuclear factor $-\kappa B(N f-\kappa B)$ proved an essential role in the development of IBD lesions due to an impaired suppressive Treg cell [97] (Fig. 1).

\section{Background of CHINESE yam}

The genus Dioscorea includes more than 600 species of flowering plants in the Dioscoreaceae family, worldwide in tropical and temperate regions [13]. Chinese yam (Dioscorea polystachya and Dioscorea opposita), also known cinnamon-vine [99]. In the China language, it is referred to as huáishān [100], an endemic species of flowering plant with an important invigorant and economic relevance in China [7]. The northern, southern, and central region in China, commonly cultivates Chinese yam, and is widely distributed to some Asia countries such as Korea and Japan. General composition includes starches $(43.7 \%)$, sugars $(3.39 \%)$, proteins $(3.59 \%$ to $8.93 \%)$, amino acids (2.31\% to $7.26 \%)$, vitamins and amylases, amidst others [8-10]. Furthermore, various bioactive compounds are available in Chinese yam tubers such as diosgenin, choline [101], flavonoids and polyphenols [102], and allantoin, which shows a keratolytic effect, promoting cell regeneration and healing of wounds [11]. Decades ago, it was observed that dioscorin is a potential active agent with biological activities both in vitro and in vivo, encompassing the antihypertensive, epithelial cell protecting activities, immunomodulatory, lectin, antioxidant and enzymatic reactions [103]. A current literature backed the perception of extract from Chinese yam having the potential to inhibit Akt, MAPK, and Nf- $\kappa B$ signaling pathway [104].

Diosgenin, a major active constituent, occurs abundantly in Dioscorea species, Heterosmilax species, and Trigonella foenum-graecum [105]. It was confirmed that diosgenin has shown anti-diabetes effects [106, 107] anti-apoptosis [108] as well as mitigating oxidative stress [109-111] and inflammation [112]. Reports from pharmacological studies have revealed the anti-proliferative property of diosgenin, ameliorating the vascular system in a chronic renal failure model in rats by expanding the aorta eNOS expression in the rat [113] (Fig. 2).

\section{Role of DIOSGENIN in CROHN'S disease}

The extract from Chinese yam, Diosgenin is a family of spirostanol steroid compounds having a C27 spiroketal steroids compound. It has a relative molecular mass of 414.62 and molecular formula to be $\mathrm{C}_{27} \mathrm{H}_{42} \mathrm{O}_{3}$ [114]. Diosgenin is depicted as six rings, with the initials comprising of four rings, being the steroid core, together with the attachment of two latter rings in form of ketals. It is replaced with an $\mathrm{OH}$ group situated exactly at the $3 \beta$ position of the first ring, with a double bond at the 5-6 position as well as a R-Configuration at position 25. One of its glycosides, dioscin is attached to the $3 \beta$ position of diosgenin to form saponins, often seen to be a major bioactive saponin with the effects against hypolipidemia, inflammation, allergy, viral, fungal and 


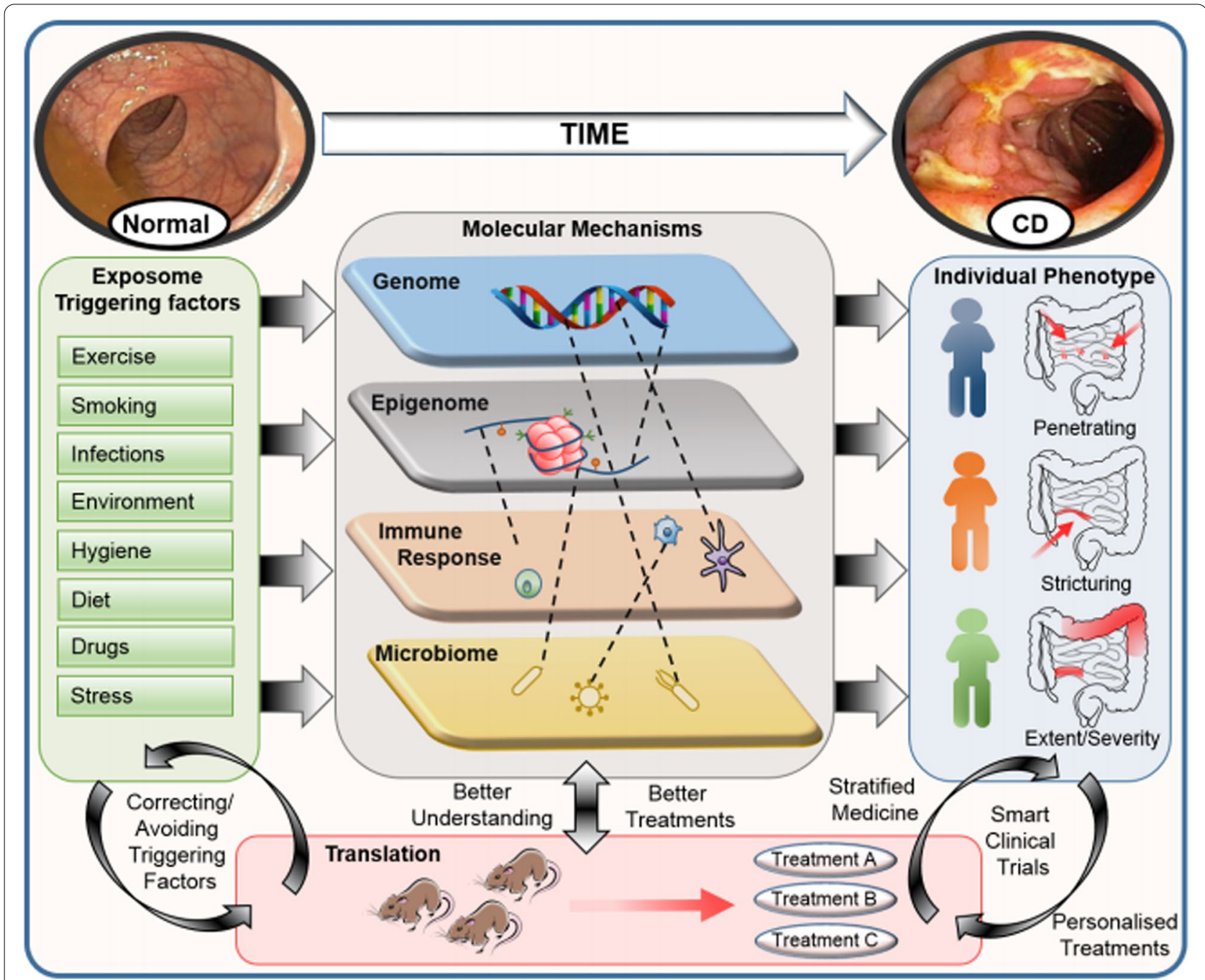

Fig. 1 Schematic representation of the multifactorial pathogenesis of Crohn's disease. Available therapeutic options are currently targeted at the environmental, immunological and genetic causes of Crohn's disease [98]

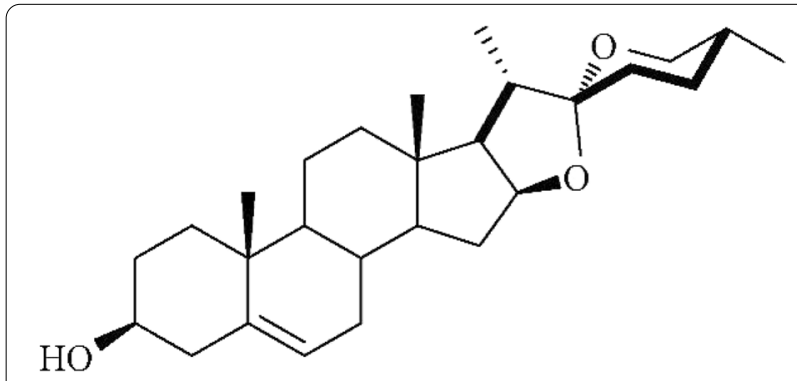

Fig. 2 Structure of Diosgenin $\{25 R$-spirost-en-3 $\beta$-ol $]$

immunoregulation [115-117]. In addition, studies have revealed that diosgenin ameliorated cholesterol secretion via the biliary excretion, restrained cholesterol absorption [118-121], altered lipoxygenase activities caused by differentiation of human erythroleukemia cell line [122], as well as cell cycle suspension in osteosarcoma cell line of human [123]. In the pathogenesis of inflammatory bowel disease (crohn's disease and ulcerative colitis), NF $\kappa \mathrm{B}$ has been identified to be one of the key regulators in the complex mechanisms such as; signaling mechanism via epithelial cells, dysregulated cytokine production, lymphocytes and macrophages. However, the transcription factor NF- $\mathrm{\kappa B}$ is expressed and activated strongly in the inflamed bowel of patient affected with IBD. Studies carried on an inflamed gut from macrophages and epithelial cells of an IBD patient depicted an increased level of NF- $\mathrm{\kappa B}$ p65 [124]. The increased level of NF-кB expression in macrophages led to the production and secretion of certain pro-inflammatory cytokines such as; TNF- $\alpha$, IL-1, IL-6, IL-12 and IL-23 which are directly affected 
in the mucosal tissue damage relating to IBD $[125,126]$. Also, lamina propria fibroblast have been hypothesized to show a NF-кB pro-inflammatory role in IBD [127]. However, a proven study on the effect of diosgenin on a bacteria-recombinant human tumor necrosis factor (TNF- $\alpha$ ) showed that diosgenin inhibited TNF mediated NF-кB activation and its regulated genes products \{c-Rel, RelA (p65), Rel B, NF-kB1 (p50 and p105) and NF-kB2 (p52) $\}$ in a dose dependent manner at $50 \mu \mathrm{m}$ and a complete annulling of NF- $\mathrm{KB}$ activity at $100 \mu \mathrm{m}$ [128]. Furthermore, the use of Western Blot analysis of an antibody detecting only serine phosphorylated form of $I k B \alpha$ affirmed that diosgenin completely suppressed TNF-induced IkB $\alpha$ phosphorylation (inhibitory subunit of NF-кB) in 5mins [129]. Thus, it has been proven that diosgenin inhibits the activation of NF- $\mathrm{\kappa B}$ by inhibiting the degradation and phosphorylation of IkB $\alpha$. Lastly, corticosteroids, a natural precursor of diosgenin $[16,17]$ has been approved to be an immunosuppressive drug on $\mathrm{IBD}$, used to induce an over-expression of IkB $\alpha$ which is known to retain NF- $\mathrm{KB}$ in the cytoplasm together with the interaction of $\mathrm{p} 65$ to inhibit the activation of NF- $\mathrm{KB}$ $[26,130-134]$. Over the years, the research community have implicated the role of inflammation and the impact of free radical induced oxidative stress in the pathogenesis of Crohn's disease, thus focusing therapeutic options toward the inhibition of inflammatory factors as well as scavenging free radicals [135-137]. The pharmacological potential of diosgenin is well placed beyond reasonable doubt. Quite a credible number of in vivo studies have shown the pharmacological potential of diosgenin to significantly ameliorates decreased body weight caused by a compromised immune system during the diseased state and elevated stool. This amelioration is however due to the suppression of inflammation by diosgenin [138-140]. The activity of oxidant such as superoxide radical, oxygen radical amidst others have been known to trigger the damage of tissues leading to the infiltration of neutrophils [141, 142]. This however leads to the secretion of myeloperoxidase which is transported within the cellular organelles to the suicide bag. The activation oof the neutrophils under duress are followed by the inflammation of the large intestine, which is however responsible for increased synthesis of reactive oxygen species [143]. As a result, the increased ROS synthesis following elevated MPO levels is responsible for inflammation attributed to Crohn's disease $[144,145]$. A very recent study by Wang et al., (2018) [146] illustrated the anti-inflammatory potential of diosgenin. Over the years, studies have stressed the link between oxidative stress (caused by an imbalance between oxidants and antioxidant synthesized in the body and the pathogenesis of inflammatory bowel diseases including Crohn's [139, 140]. It was explained that the conversion of $(\mathrm{O} 2-)$ to hydrogen peroxide leads to the disruption of intestinal membrane, causing injury to cells. However, this reaction can be reversed by glutathione. Thus, sufficient glutathione levels are enough to avoid the onset of oxidative stress [147-149]. The reversal of lipid peroxidation by diosgenin is also worthy of notable mention [150,151]. A correlation between the levels of multifunctional cytokines (inflammatory cytokines such as TNF- $\alpha$, IL- $1 \beta$, IL- 6 , and IFN- $\gamma$ ) and the pathogenesis of Crohn's via the inhibition of regulatory T-cell function and activation of $\mathrm{T}$ helper type 1 (Th1) cells [139-152]. However, it was observed that administration of diosgenin lead to the attenuation of these inflammatory cytokines thereby expressing its essential anti-inflammatory potential in the management of Crohn's diseases $[146,153]$. The intrinsic or extrinsic cell death cascade is triggered follow the onset of Crohn's diseases following the expression of Bax and Caspases-1 [154, 155]. However, investigation have reported the efficacy of diosgenin in inhibiting Bax and Caspases-1 induced apoptosis [156]. This was observed to be in accordance to the findings of Raju et al. (2004) on diosgenin [157]. Although the management of IBD with herbal mixtures is beginning to gain prominence, the effectiveness of diosgenin have however been placed beyond reasonable doubts in clinical research especially in the management of IBD. Several other pharmacological potentials of diosgenin have been include its anti-cancer effects, suppression of lipoxygenase inhibition of CXCR3, and induction of $\mathrm{Ca} 2+$ release [158-160]. An essential factor in the regulation of genetic products are the signal transducer and activator of transcription (STAT) family, playing important role in proliferation and survival of cells. This factor (STAT) becomes activated via the upregulation of by Janus kinases (JAK), or the Src family kinases, thus allowing STAT to dimerize and translocate while binding to the promoters of target genes $[161,162]$.

Of this large family, STAT3 is the most linked family associated with the promotion of the pro-inflammatory cytokines as well as supporting the growth of malignant cells. This is done by upregulating NF- $\mathrm{kB}$, a deleterious factor whose effect have been discussed in this section. Briefly, the NF-kB-regulated Interleukin 6 (IL6) binds to IL6 receptor which via interaction with few subunits leads to the activation of (STAT)3. This in return regulates the activity of (SOCS) 3; essential in the suppression of cytokine activity $[163,164]$. SOCS group of protein are involved in the negative feedback regulation of the JAK/ Src family kinases, thus invariably regulating the signaling of STAT. The expression of SOCS3 have been found in IBD rat mode, thus suggesting a possible role in the pathogenesis of Crohn's and Colitis $[165,166]$.The role of IL6/STAT3/SOCS3 in the regulation of homeostasis have 
been well explained, as such the inflammation observed in Crohn's disease is as a result of the striking imbalance between SOCS3 expression and IL6/STAT3 signaling $[167,168]$. It is worthy to note, IL6/STAT3 signaling, including constitutive activation of STAT3, was found to generally mediate development and progression of colorectal adenoma and carcinoma without inflammation in background $[168,169]$, in which IL6/STAT3 may be activated by microbial translocation through impaired mucosal barrier and function in physiological modulation of mucosal immunity (Fig. 3).

The pharmacological significance of diosgenin on STAT3 phosphorylation was observed to be in correlation with the repression of upstream c-Src, JAK1 and JAK2 protein kinases. Earlier investigation suggested that the role of Src and JAK1 kinase activities acts in synergy to regulate the constitutive activation of STAT3 $[170,171]$. However, the findings by Feng et al., (2009)
[172] suggested that diosgenin blocks the synergistic cooperation of Src and JAKs involved in tyrosyl phosphorylation of STAT3. Furthermore, the mechanism at which JAK2, mitogen-activated protein kinase, and Akt activates STAT3 activation have been explained beforehand [173, 174]. Albeit, suppression of IL-6-induced Akt activation and nuclear translocation was pharmacologically mediated by diosgenin [172]. This however suggests that diosgenin exerts its pharmacological potential in quite diverse ways. While we have stated that diosgenin is capable of inactivating NF-kB, it was reported that STAT3 prolongs NF-kB retention via the actylation of acetyltransferase p300-mediated RelA acetyltransferase p300-mediated RelA [175]. Some glittering evidences also showed that diosgenin-triggered inhibition of STAT3 activation is only possible via the recruitment of protein tyrosine phosphatase (PTP) [176, 177]. The biochemical significance of PTP can be properly read from studies by

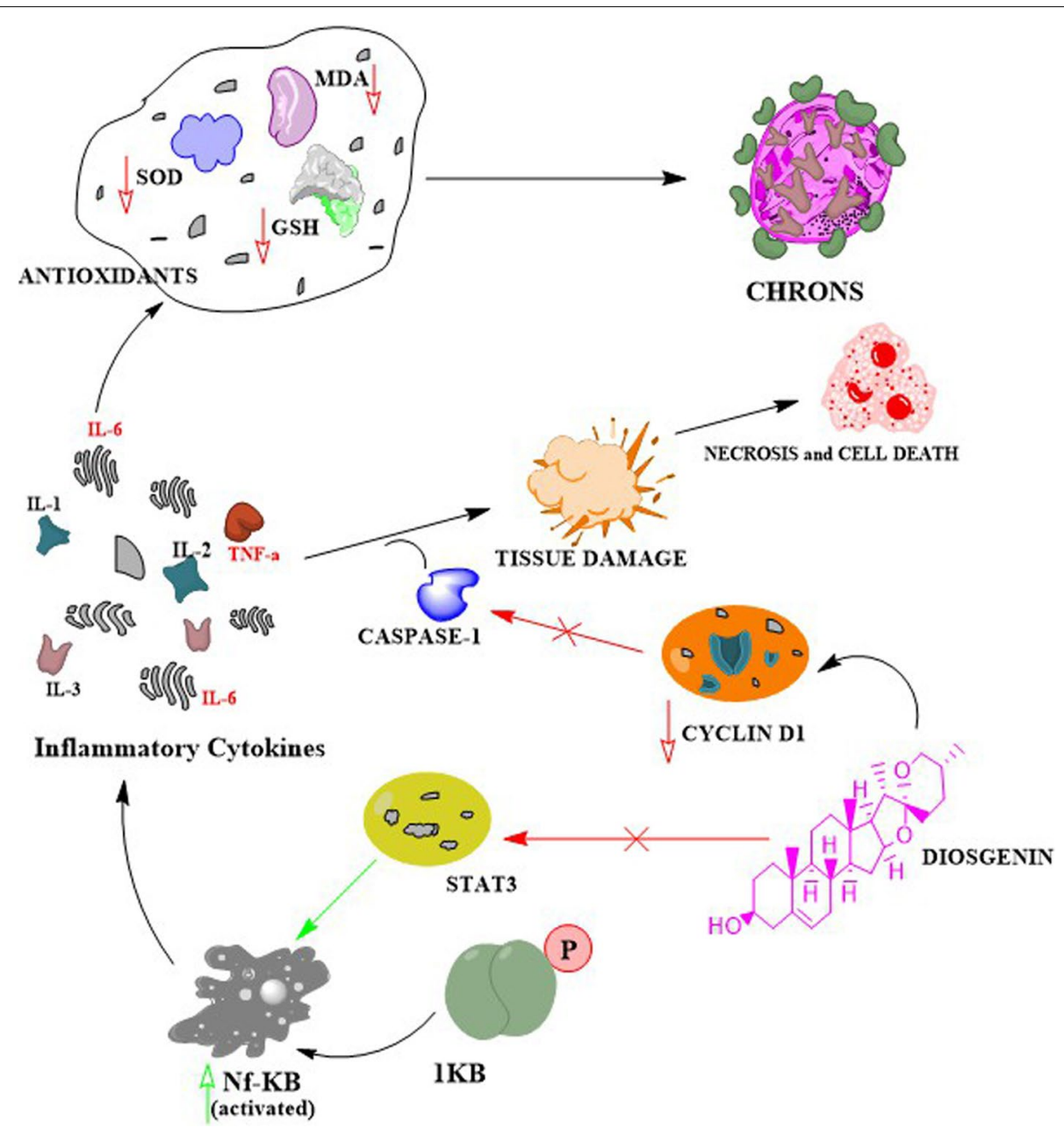

Fig. 3 Depicting the role of diosgenin in Crohn's disease. The phosphorylation of $1 \mathrm{~kb}$ allows for the upregulation Nf-kb is kept upregulated by STAT3 and leads to the activation of inflammatory cytokines; a pre-requisite to Crohn's disease. However, the administration of diosgenin blocks these reactions, thus preventing necrosis and cell death 
Servidei et al., (1998) and Aggarwal et al., (2009) [178, 179]. While the stimulation of the expression of SHPTP2 protein leading to the downregulation of constitutive STAT3 phosphorylation is clear, it is however safe to say that the diosgenin however possess a strong pharmacological basis that could be essential in the management of Crohn's disease.

\section{Conclusion \& future perspective}

The quest to provide therapeutic solutions to several medical conditions have been a cause of concern not only to the scientific community, but to human population at large. Scientists in the field of drug discovery and development works round the clock to ensure that the mayhem caused by this disease are put to check. Diosgenin is one of the major bioactive compounds found in Chinese yam. Several preclinical studies as regard its pharmacological activities against hypolipidemia, diabetes, cancer, inflammation, allergy, viral and fungal infection have been detailed. We observed that diosgenin inhibited TNF mediated NF-KB activation and its regulated genes products \{c-Rel, RelA (p65), Rel B, NF-kB1 (p50 and p105) and NF-kB2 (p52)\} in a dose dependent manner, thus it is potent in the management of Crohn's diseases. While invivo studies has affirmed the efficacy of diosgenin, the challenge to conform invivo studies to human clinical trials still persists. The shift of focus to genetic approach in developing a therapeutic agents should be applauded. Although limited amount of translational research still remains a problem to contend with in the scientific community, future studies should endeavor to shed more light on the use of emerging technologies as a powerful agent in the development of Crohn's diseases therapy.

\begin{abstract}
Abbreviatons
IBD: Inflammatory bowel disease; CD: Crohn's disease; anti-TNF: Anti-tumor necrosis factor; NF-kB: Nuclear factor kappa light chain enhancer of activated B cells; GWA: Genomics Wide Association; NOD2: Nucleotide-binding oligomerization domain-containing protein 2; MAPK/ERK: Mitogen-activated protein kinase; IL-3: Interleukin-3; IL-12: Interleukin-12; JAK 3: Janus Kinase 3; MDP: Muramyl dipeptide; IRGM: Immunity related GTPase family M; IFN-ү: Interferon-gamma; Th17:T helper 17; TLR-2: Toll-like receptor -2; ATG16L1: Autophagy-related 16-like 1; CARD 15: Caspase recruitment domain 15; IL23R: Interleukin 23- receptor; LRRK2: Leucine-rich repeat kinase 2; TGF- $\beta$ : Transforming growth factor- $\beta$; RIPK2: Receptor-interacting protein serine-threonine kinase 2; IKBa: Inhibitor of kinase B-a; CCR6: Chemokine receptor 6; Foxp3: Forkhead box P3; STAT3: Signal transducer and activator of transcription 3; TYK2: Tyrosine kinase 2; ATG7/5: Autophagosome 7/5; MHC: Major histocompatibility complex; CXCR3: Chemokine receptor 3.
\end{abstract}

\section{Acknowledgments}

We appreciate our teachers (DR Abiodun Owoade, Dr. Peter Ifeoluwa Adegboola, Dr. Olumide Fadahunsi and Dr. T.I Adelusi) from the Department of Biochemistry, Ladoke Akintola University of Technology, Ogbomoso, Nigeria.

\section{Authors' contributions}

Author AA conceived the idea; Author OS, OM, OJ, AD and OJ gathered information and developed the manuscript; Author AA proofread and edited the manuscript. All authors read and approved the final manuscript for submission.

Funding

This work is not funded by anybody or organization.

Availability of data and materials

Not applicable.

\section{Declarations}

Ethics approval and consent to participate

Not applicable.

\section{Consent for publication}

Not applicable.

\section{Competing interests}

Authors declare that they have no competing interest.

\section{Author details}

${ }^{1}$ Department of Biochemistry, Faculty of Basic Medical Sciences, Ladoke Akintola University of Technology, Ogbomosho, Oyo State, Nigeria. ${ }^{2}$ Department of Food Science and Technology, Micheal Okpara University of Agriculture, Umudike, Nigeria. ${ }^{3}$ Department of Human Nutrition and Dietetics, Faculty of Public Health, University of Ibadan, Ibadan, Nigeria. ${ }^{4}$ Department of Pharmacology, Faculty of Pharmaceutical Sciences, Enugu State University of Technology, Enugu, Nigeria. ${ }^{5}$ Department of Biochemistry, Faculty of Biological Sciences, University of Nigeria, Nsukka, Nigeria. ${ }^{6}$ Pharmacology/ Physiology Unit, Department of Science Laboratory Technology, University of Nigeria, Nsukka, Nigeria.

Received: 20 January 2021 Accepted: 16 January 2022

Published online: 07 February 2022

\section{References}

1. GBD 2017 Inflammatory bowel disease collaborators. The global, regional, and national burden of inflammatory bowel disease in 195 countries and territories, 1990-2017: a systematic analysis for the global burden of disease study 2017. Lancet Gastroenterol Hepatol. 2020(5):17-30. https://doi.org/10.1016/S2468-1253(19)30333-4.

2. Abraham C, Cho JH. Inflammatory bowel disease. N Engl J Med. 2009;361:2066-78.

3. Boyapati R, Satsangi J, Ho GT. Pathogenesis of Crohn's disease. F1000Prime Rep. 2015;2(7):44. https://doi.org/10.12703/P7-44.

4. Peyrin-Biroulet L, Loftus EV, Colombel J, Sandborn WJ. The natural history of adult Crohn's disease in population-based cohorts. Am J Gastroenterol. 2010;105:289-97.

5. Beaugerie L, Seksik P, Nion-Larmurier I, Gendre J, Cosnes J. Predictors of Crohn's disease. Gastroenterology. 2006;130:650-6.

6. Colombel JF, Sandborn WJ, Reinisch W, Mantzaris GJ, Kornbluth A, Rachmilewitz D, et al. Infliximab, azathioprine, or combination therapy for Crohn's disease. N Engl J Med. 2010;362:1383-95.

7. Ma J, Clemants S. A history and overview of the Flora Reipublicae Popularis Sinicae (FRPS, Flora of China, Chinese edition). 2006:55(2)451-60.

8. Omonigho SE, lkenebomeh MJ. Effects of different preservative treatments on the chemical changes of pounded white yam (Dioscorea rotundata) in storage at $28 \pm 2{ }^{\circ} \mathrm{C}$. Food Chem. 2000;68:201-9.

9. Yuan SL. Research advances on chemical compositions and bioactivities of Dioscorea opposite thumb. (Chinese yam). Food Res Dev. 2008;29(3):176-9.

10. Zhou YF, WuY ZYM, Yan YH. The manufacture and utilization of Chinese yam. Anhui Agric Sci Bull. 2004;10:65-6.

11. Fu YC, Ferng LHA, Huang PY. Quantitative analysis of allantoin and allantoic acid in yam tuber, mucilage, skin and bulbil of the Dioscorea species. Food Chem. 2006;94:541-9. 
12. Yang DJ, Lin JT. Effects of different storage conditions on steroidal saponins in yam (Dioscorea pseudojaponica Yamamoto) tubers. Food Chem. 2008;110:670-7.

13. Adedayo CB, Oboh G, Ademiluyi AO, Akindaahunsi AA. Comparative studies on antioxidant properties of some tropical Nigerian yam varieties (Dioscorea spp.). Adv Food Sci. 2011;33:28-33.

14. Raju J, Mehta R. Cancer chemopreventive and therapeutic effects of diosgenin, a food saponin. Nutr Cancer. 2009;61:27-35.

15. Gupta MM, Farooqui SU, Lal RN. Distribution and variation of diosgenin in different parts of Costus speciosus. J Nat Prod. 1981;44:486-9.

16. Shao B, Guo H, Cui Y, Ye M, Han J, Guo D. Steroidal saponins from Smilax China and their anti-inflammatory activities. Phytochemistry. 2007;68:623-30

17. Dong J, Lei C, Lu D, Wang Y. Direct biotransformation of dioscin into diosgenin in rhizome of Dioscorea zingiberensis by Penicillium dioscin. Indian J Microbiol. 2015;55(2):200-6.

18. Al Jasem $Y$, Khan M, Taha A, Thiemann T. Preparation of steroidal hormones with an emphasis on transformations of phytosterols and cholesterol-a review. Mediterranean J Chem. 2014;3(2):796-830.

19. Gautam S, Muthu S, Sudha W, Myriam M, Frank A, Alan K, et al. Proapoptotic and anti-cancer properties of diosgenin: a comprehensive and critical review. Nutrients. 2018;10:645-57. https://doi.org/10.3390/ nu10050645

20. Lv Y-C, Yang J, Yao F, Xie W, Tang Y-Y, Ouyang X-P, et al. Diosgenin inhibits atherosclerosis via suppressing the MiR-19b-induced downregulation of ATPbinding cassette transporter A1. Atherosclerosis. 2015;240:80-9. https://doi.org/10.1016/j.atherosclerosis.2015.02.044.

21. M.A. Tikhonova, C.-H. Yu, N.G. Kolosova, L.A. Gerlinskaya, S.O. Maslennikova, A.V. Yudina, T.G. Amstislavskaya, Y.-J. Ho, Comparison of behavioral and biochemical deficits in rats with hereditary defined or D-galactoseinduced accelerated senescence: evaluating the protective effects of diosgenin, Pharmacol Biochem Behav 2014, (120): 7-16, https://doi. org/https://doi.org/10.1016/j.pbb.2014.01.012.

22. Wang L, Walia B, Evans J, Gewirtz AT, Merlin D, Sitaraman SV. IL-6 induces NF-kappa B activation in the intestinal epithelia. J Immunol. 2003;171:3194-201.

23. Nenci A, Becker C, Wullaert A, Gareus R, van Loo G, Danese S, et al. Epithelial NEMO links innate immunity to chronic intestinal inflammation. Nature. 2007;446:557-61.

24. Zaph C, Troy AE, Taylor BC, Berman-Booty LD, Guild KJ, Du Y, et al. Epithelial-cell-intrinsic IKK-beta expression regulates intestinal immune homeostasis. Nature. 2007:446:552-6.

25. Auphan N, DiDonato JA, Rosette C, Helmberg A, Karin M. Immunosuppression by glucocorticoids: inhibition of NF-kappaB activity through induction of I kappa B synthesis. Science. 1995;270:286-90.

26. Thiele K, Bierhaus A, Autschbach F, Hofmann M, Stremmel W, Thiele $\mathrm{H}$, et al. Cell specific effects of glucocorticoid treatment on the NFkappaBp65 / IkappaBalpha system in patients with Crohn's disease. Gut. 1999;45:693-704

27. Pg HH, McKenzie BS, Hue S, Thompson C, Joyce-Shaikh B, Stepankova R, Robinson N, Buonocore S, Tlaskalova-Hogenova H, Cua DJ, Powrie F. Differential activity of IL-12 and IL-23 in mucosal and systemic innate immune pathology. Immunity. 2006;25:309-18.

28. Schultz MButt A. Is the north to south gradient in inflammatory bowel disease a global phenomenon? Expert Rev Gastroenterol Hepatol. 2012;6(4):445-7.

29. Vind I, Riis L, Jess T, Knudsen E. Increasing incidences of inflammatory bowel disease and decreasing surgery rates in Copenhagen City and county, 2003-2005: A population-based study from the Danish Crohn colitis database. Am J Gastroenterol. 2006;101(6):1274-82.

30. Yapp T, Stenson R, Thomas G. Crohn's disease incidence in Cardiff from 1930: an update for 1991-1995. Eur J Gastroenterol Hepatol. 2000;12(8):907-11.

31. Rubin G, Hungin A, Kelly P. Inflammatory bowel disease: epidemiology and management in an English general practice population. Aliment Pharmacol Ther. 2000;14(12):1553-9.

32. Loftus C, Loftus E, Harmsen S. Update on the incidence and prevalence of Crohn's disease and ulcerative colitis in Olmsted County, Minnesota, 1940-2000. Inflamm Bowel Dis. 2007;13(3):254-61.
33. Bernstein C, Wajda A, Svenson L. The epidemiology of inflammatory bowel disease in Canada: A population-based study. Am J Gastroenterol. 2006;101(7):1559-68.

34. Dignass A, Van Assche G, Lindsay JO, et al. The second European evidence-based consensus on the diagnosis and management of Crohn's disease: current management. J Crohns Colitis. 2010;4:28-62.

35. Joana Torres, Saurabh Mehandru, Jean-Frédéric Colombel, Laurent Peyrin-Biroulet. Crohn's disease Division of Gastroenterology, cahn School of Medicine at Mount Sinai, New York City, NY, USA 2016. https://doi. org/10.1016/S0140-6736(16)31711-1

36. Halme L, Paavola-Sakki P, Turunen U, Lappalainen M, Farkkila M, Kontula K. Family and twin studies in inflammatory bowel disease. World J Gastroenterol. 2006;12:3668-72.

37. Jostins L, Ripke S, Weersma RK, et al. Host-microbe interactions have shaped the genetic architecture of inflammatory bowel disease. Nature. 2012:491:119-24.

38. Franke A, McGovern DPB, Barrett JC, Wang K, Radford- Smith GL, Ahmad $T$, et al. Genome-wide meta-analysis increases to 71 the number of confirmed Crohn's disease susceptibility loci. Nat Genet. 2010;42:1118-25.

39. Guo QS, Xia B, Jiang Y, Qu Y, Li J. NOD2 3020insC frameshift mutation is not associated with inflammatory bowel disease in Chinese patients of Han nationality. World J Gastroenterol. 2004;10:1069-71.

40. Baumgart DC, Sandborn WJ. Crohn's disease. Lancet. 2012;380:1590-605.

41. Lee JC, Parkes M. Genome-wide association studies and Crohn's disease. Brief Funct Genomics. 2011;10(2):71-6.

42. Cuthbert AP, Fisher SA, Mirza MM, King K, Hampe J, Croucher PJP, et al. The contribution of NOD2 gene mutations to the risk and site of disease in inflammatory bowel disease. Gastroenterology. 2002;122:867-74.

43. Jiang W, Wang $X$, Zeng B, Liu L, Tardivel A, Wei H, et al. Recognition of gut microbiota by NOD2 is essential for the homeostasis of intestinal intraepithelial lymphocytes. J Exp Med. 2013;210:2465-76.

44. Bevins CL, Stange EF, Wehkamp J. Decreased Paneth cell defensin expression in ileal Crohn's disease is independent of inflammation, but linked to the NOD2 1007fs genotype. Gut. 2009;58:882-3.

45. Cooney R, Baker J, Brain O, Danis B, Pichulik T, Allan P, et al. NOD2 stimulation induces autophagy in dendritic cells influencing bacterial handling and antigen presentation. Nat Med. 2010;16:90-7.

46. van Heel DA, Ghosh S, Hunt KA, Mathew CG, Forbes A, Jewell DP, et al Synergy between TLR9 and NOD2 innate immune responses is lost in genetic Crohn's disease. Gut. 2005;54:1553-7.

47. Brain O, Owens BMJ, Pichulik T, Allan P, Khatamzas E, Leslie A, et al. The intracellular sensor NOD2 induces microRNA-29 expression in human dendritic cells to limit IL-23 release. Immunity. 2013;39:521-36.

48. Kobayashi K, Inohara N, Hernandez LD, Galan JE, Núñez G, Janeway CA, et al. RICK/Rip2/CARDIAK mediates signalling for receptors of the innate and adaptive immune systems. Nature. 2002;416:194-9.

49. Abbott DW, Yang Y, Hutti JE, Madhavarapu S, Kelliher MA, Cantley LC. Coordinated regulation of toll-like receptor and NOD2 signaling by K63-linked polyubiquitin chains. Mol Cell Biol. 2007;27:6012-25.

50. Yang Y, Yin C, Pandey A, Abbott D, Sassetti C, Kelliher MA. NOD2 pathway activation by MDP or mycobacterium tuberculosis infection involves the stable polyubiquitination of Rip2. J Biol Chem. 2007;282:36223-9.

51. Hasegawa M, Fujimoto Y, Lucas PC, Nakano H, Fukase K, Núñez G, et al. A critical role of RICK/RIP2 polyubiquitination in nod-induced NF-_B activation. EMBO J. 2008;27:373-83.

52. Yoshimura T, Matsushima K, Tanaka S, Robinson EA, Appella E, Oppenheim JJ, et al. Purification of a human monocyte- derived neutrophil chemotactic factor that has peptide sequence similarity to other host defense cytokines. Proc Natl Acad Sci U S A. 1987;84:9233-7.

53. Waugh DJ, Wilson C. The interleukin-8 pathway in cancer. Clin Cancer Res. 2008;14:6735-41.

54. Xie K. Interleukin-8 and human cancer biology. Cytokine Growth Factor Rev. 2001;12:375-91.

55. Brat DJ, Bellail AC, Van Meir EG. The role of interleukin-8 and its receptors in gliomagenesis and tumoral angiogenesis. Neuro-Oncology. 2005; 7:122-33.

56. Beste MT, Pfaffle-Doyle N, Prentice EA, Morris SN, Lauffenburger DA Isaacson KB, et al. Molecular network analysis of endometriosis reveals 
a role for c-Jun-regulated macrophage activation. Sci Transl Med. 2014;30:79-88.

57. Tanghetti EA. The role of inflammation in the pathology of acne. J Clin Aesthet Dermatol. 2013;6:27-35.

58. Li J, Moran T, Swanson E, Julian C, Harris J, Bonen DK, et al. Regulation of IL-8 and IL-1_expression in Crohn's disease associated NOD2/CARD15 mutations. Hum Mol Genet. 2006:13:1715-25.

59. Lappalainen M, Paavola-Sakki P, Halme L, Turunen U, Fa"rkkila", M., Repo, H., and Kontula, K. Novel CARD15/NOD2 mutations in Finnish patients with Crohn's disease and their relation to phenotypic variation in vitro and in vivo. Inflamm Bowel Dis. 2008;14:176-85.

60. van Heel DA, Hunt KA, King K, Ghosh S, Gabe SM, Mathew CG, et al. Detection of muramyl dipeptide- sensing pathway defects in patients with Crohn's disease. Inflamm Bowel Dis. 2006;12:598-605.

61. Levine B, Kroemer G. Autophagy in the pathogenesis of disease. Cell. 2008; 132:27-42.

62. Travassos LH, Carneiro Leticia AM, Ramjeet M, Hussey S, Kim Y, Magalhães JG, et al. Nod1 and Nod2 direct autophagy by recruiting ATG16L1 to the plasma membrane at the site of bacterial entry. Nat Immunol. 2010:11:55-62.

63. Mahid SS, Minor KS, Soto RE, Hornung CA, Galandiuk S. Smoking and inflammatory bowel disease: a meta-analysis. Mayo Clin Proc. 2006;81:1462-71.

64. Sopori M. Effects of cigarette smoke on the immune system. Nat Rev Immunol. 2002;2:372-7.

65. Helbig KL, Nothnagel M, Hampe J, Balschun T, Nikolaus S, Schreiber S. A case-only study of gene-environment interaction between genetic susceptibility variants in NOD2 and cigarette smoking in Crohn's disease aetiology. BMC Med Genet. 2012;13:14

66. Amre DK, D'Souza S, Morgan K, et al. Imbalances in dietary consumption of fatty acids, vegetables, and fruits are associated with risk for Crohn's disease in children. Am J Gastroenterol. 2007;102(9):2016-25.

67. Sakamoto N, Kono S, Wakai K, et al. Epidemiology Group of the Research Committee on inflammatory bowel disease in Japan. Dietary risk factors for inflammatory bowel disease: a multicenter case-control study in Japan. Inflamm Bowel Dis. 2005;11(2):154-63.

68. Hou JK, Abraham B, El-Serag H. Dietary intake and risk of developing inflammatory bowel disease: a systematic review of the literature. Am J Gastroenterol. 2011;106(4):563-73.

69. Ananthakrishnan AN, Higuchi LM, Huang ES, et al. Aspirin, nonsteroidal anti-inflammatory drug use, and risk for Crohn disease and ulcerative colitis: a cohort study. Ann Intern Med. 2012;156(5):350-9.

70. García Rodríguez LA, González-Pérez A, Johansson S, Wallander MA. Risk factors for inflammatory bowel disease in the general population. Aliment Pharmacol Ther. 2005;22(4):309-15.

71. Kronman MP, Zaoutis TE, Haynes K, Feng R, Coffin SE. Antibiotic exposure and IBD development among children: a population-based cohort study. Pediatrics. 2012;130(4):e794-803.

72. Cornish JA, Tan E, Simillis C, Clark SK, Teare J, Tekkis PP. The risk of oral contraceptives in the etiology of inflammatory bowel disease: a metaanalysis. Am J Gastroenterol. 2008;103(9):2394-400

73. Khalili H, Higuchi LM, Ananthakrishnan AN. Hormone therapy increases risk of ulcerative colitis but not Crohn's disease. Gastroenterology. 2012;143(5):1199-206.

74. Sansonetti PJ. War and peace at mucosal surfaces. Nat Rev Immunol. 2004:4:953-64.

75. Cheifetz AS. Management of active Crohn disease. JAMA. 2013;309(20):2150-8.

76. Garcia-Lafuente A, Antolin M, Guarner F, Crespo E, Malagelada JR. Modulation of colonic barrier function by the composition of the commensal flora in the rat. Gut. 2001;48:503-7.

77. Kostic AD, Xavier RJ, Gevers D. The microbiome in inflamatory bowel disease: current status and the future ahead. Gastroenterology. 2014:146:1489-99.

78. Izcue A, Hue S, Buonocore S, Arancibia-Cárcamo CV, Ahern PP, Iwakura $Y$, et al. Interleukin-23 restrains regulatory $T$ cell activity to drive T celldependent colitis. Immunity. 2008;28:559-70.

79. Cobrin GM, Abreu MT. Defects in mucosal immunity leading to Crohn's disease. Immunol Rev. 2005;206:277-95.
80. Neurath MF, Weigmann B, Finotto S. The transcription factor T-bet regulates mucosal T cell activation in experimental colitis and Crohn's disease. J Exp Med. 2002;195:1129-43.

81. Monteleone G, Trapasso F, Parrello T, et al. Bioactive IL-18 expression is up-regulated in Crohn's disease. J Immunol. 1999;163:143-7.

82. Pizarro TT, Michie MH, Bentz M, et al. IL-18, a novel immunoregulatory cytokine, is up-regulated in Crohn's disease: expression and localization in intestinal mucosal cells. J Immunol. 1999;162:6829-35.

83. Kugathasan S, Saubermann LJ, Smith L, et al. Mucosal T-cell immunoregulation varies in early and late inflammatory bowel disease. Gut. 2007;56:1696-705.

84. Dambacher J, Beigel F, Zitzmann K, et al. The role of the novel Th17 cytokine IL-26 in intestinal inflammation. Gut Published Online First: May 2008,30:1-12 doi:https://doi.org/10.1136/gut2007.130112.

85. Pene J, Chevalier S, Preisser $L$, et al. Chronically inflamed human tissues are infiltrated by highly differentiated Th17 lymphocytes. J Immunol. 2008;180:7423-30.

86. Annunziato F, Cosmi L, Santarlasci V, et al. Phenotypic and functional features of human Th17 cells. J Exp Med. 2007;204:1849-61.

87. Acosta-Rodriguez EV, Rivino L, Geginat J, et al. Surface phenotype and antigenic specificity of human interleukin 17 - producing $T$ helper memory cells. Nat Immunol. 2007:8:639-46.

88. Fujino S, Andoh A, Bamba S, Ogawa A, Hata K, Araki Y, et al. Increased expression of interleukin 17 in inflammatory bowel disease. Gut. 2003;52:65-70.

89. Andoh A, Zhang Z, Inatomi O, Fujino S, Deguchi Y, Araki Y, et al. Interleukin-22, a member of the IL-10 subfamily, induces inflammatory responses in colonic subepithelial myofibroblasts. Gastroenterology. 2005;129:969-84

90. Di Sabatino A, Rovedatti L, Kaur R, Spencer JP, Brown JT, Morisset VD, et al. Targeting gut $T$ cell $\mathrm{Ca} 2+$ release-activated $\mathrm{Ca} 2+$ channels inhibits T cell cytokine production and T-box transcription factor T-bet in inflammatory bowel disease. J Immunol. 2009;183:3454-62.

91. Kleinschek MA, Boniface K, Sadekova S, Grein J, Murphy EE, Turner SP, et al. Circulating and gutresident human Th17 cells express CD161 and promote intestinal inflammation. J Exp Med. 2009;206:525-34.

92. Hasanjani RM, Bayani M, Soleimani AS, Mohammadnia-Afrouzi M, Nouri H, Ebrahimpour S. Evaluation of CD4+ CD25+ FoxP3+ regulatory T-cells during treatment of patients with brucellosis. J Biol Regul Homeost Agents. 2016;30(3):675

93. Mohammadnia-Afrouzi M, Shahbazi M, Damavandi SB, Ganji GF, Ebrahimpour S. Regulatory T-cell: regulator of host defense in infection. J Mol Biol Res. 2017;7(1):9.

94. Li Y, Wang Y, Liu Y, Wang Y, Zuo X, Li Y, et al. The possible role of the novel cytokines IL-35 and IL-37 in inflammatory bowel disease. Mediat Inflamm. 2014:2014:10

95. Liu Z, Feng B-S, Yang S-B, Chen X, Su J, Yang P-C. Interleukin (IL)-23 suppresses IL-10 in inflammatory bowel disease. J Biol Chem. 2012;287(5):3591-7.

96. Glocker E, Kotlarz D, Boztug K, Gertz EM, Schäffer AA, Noyan F, et al. Inflammatory bowel disease and mutations affecting the interleukin-10 receptor. N Engl J Med. 2009;361:2033-45.

97. Ishimaru N, Yamada A, Kohashi M, Arakaki R, Takahashi T, Izumi K, et al. Development of inflammatory bowel disease in long-Evans cinnamon rats based on CD4+CD25+Foxp3+ regulatory T cell dysfunction. J Immunol. 2008;180:6997-7008.

98. Boyapati R, Satsangi J, Ho GT. Pathogenesis of Crohn's disease. F1000Prime Rep. 2015;2(7):44. https://doi.org/10.12703/P7-44.

99. Deegan S, Saveljeva S, Gorman AM, Samali A. Stress-induced self-cannibalism: on the regulation of autophagy by endoplasmic reticulum stress. Cell Mol Life Sci. 2013;70:2425-41. https://doi.org/ 10.1007/s00018-012-1173-1174.

100. Adolph TE, Tomczak MF, Niederreiter L, Ko H, Böck J, Martinez-Naves E, Glickman JN, Tschurtschenthaler M, Hartwig J, Hosomi S, Flak MB, Cusick JL, Kohno K, Iwawaki T, Billmann-Born S, Raine T, Bharti R, Lucius R, Kweon M, Marciniak SJ, Choi A, Hagen SJ, Schreiber S, Rosenstiel P, Kaser A, Blumberg RS. Paneth cells as a site of origin for intestinal inflammation. Nature. 2013;503:272-6.

101. El H. Final report of the amended safety assessment of Dioscorea villosa (wild yam) root extract. Int J Toxicol. 2004;23:49-54. https://doi. org/10.1080/10915810490499055. 
102. Yang W, Wang Y, Li X, Yu P. Purification and structural characterization of Chinese yam polysaccharide and its activities. Carbohydr Polym. 2015;117:1021-7

103. Xue YL, Miyakawa T, Sawanoa Y, Tanokura M. Cloning of genes and enzymatic characterizations of novel dioscorin isoforms from Dioscorea japonica. Plant Sci. 2012;183(1):14-9. https://doi.org/10. 1016/j.plantsci.2011.10.021

104. Choi EM, Koo SJ, Hwang JK. Immune cell stimulating activity of mucopolysaccharides isolated from yam (Dioscorea batatas). J Ethnopharmacol. 2004;91:1-6.

105. Yi T, Fan LL, Chen $\mathrm{HL}$, et al. Comparative analysis of diosgenin in Dioscorea species and related medicinal plants by UPLC-DAD-MS. BMC Biochem. 2014;15(1):9.

106. Roghani-Dehkordi M, Roghani T. Baluchnejadmojarad, Diosgenin mitigates Streptozotocin diabetes-induced vascular dysfunction of the rat aorta: the involved mechanisms. J Cardiovasc Pharmacol. 2015;66:584-92.

107. Saravanan P, Ponmurugan MA, Deepa B. Senthilkumar, modulatory effects of diosgenin on attenuating the key enzymes activities of carbohydrate metabolism and glycogen content in streptozotocin-induced diabetic rats. Can J Diabetes. 2014;38:409-14.

108. Zhang J, Wang H. Morroniside protects against chronic atrophic gastritis in rat via inhibiting inflammation and apoptosis. Am J Transl Res. 2019;11(9):6016-23.

109. Ahmed LA, Obaid AA, Zaki HF, Agha AM. Role of oxidative stress, inflammation, nitric oxide and transforming growth factor-beta in the protective effect of diosgenin in monocrotaline-induced pulmonary hypertension in rats. Eur J Pharmacol. 2014;740:379-87.

110. Pari L, Monisha P, Mohamed Jalaludeen A. Beneficial role of diosgenin on oxidative stress in aorta of streptozotocin induced diabetic rats. Eur J Pharmacol. 2012;691:143-50.

111. Tharaheswari M, Jayachandra Reddy N, Kumar R, Varshney KC, Kannan M, Sudha Rani S. Trigonelline and diosgenin attenuate ER stress, oxidative stressmediated damage in pancreas and enhance adipose tissue PPARgamma activity in type 2 diabetic rats. Mol Cell Biochem. 2014;396:161-74.

112. Wang HW, Liu HJ, Cao H, Qiao ZY, Xu YW. Diosgenin protects rats from myocardial inflammatory injury induced by ischemia-reperfusion. Med Sci Monit. 2018;24:246-53.

113. Manivannan J, Balamurugan E, Silambarasan T, Raja B. Diosgenin improvesvascular function by increasing aortic eNOS expression, normalize dyslipidemiaand ACE activity in chronic renal failure rats. Mol Cell Biochem. 2013;384:113-20.

114. Blunden $\mathrm{G}$, Rhodes $\mathrm{CT}$. Stability of diosgenin. J Pharm Sci. 1968;57(4):602-4.

115. Okawara M, Tokudome $Y$, Todo H, Sugibayashi K, Hashimoto F. Effect of $\beta$-cyclodextrin derivatives on the diosgenin absorption in Caco-2 cell monolayer and rats. Biol Pharm Bull. 2014;37(1):54-9.

116. Okawara M, Tokudome Y, Todo H, Sugibayashi K, Hashimoto F. Enhancement of diosgenin distribution in the skin by cyclodextrin complexation following oral administration. Biol Pharm Bull. 2013;36(1):36-40

117. Okawara M, Hashimoto F, Todo H, Sugibayashi K, Tokudome Y. Effect of liquid crystals with cyclodextrin on the bioavailability of a poorly watersoluble compound, diosgenin, after its oral administration to rats. Int J Pharm. 2014;472(2):257-61.

118. Cayen MN, Dvomik D. Effects of diosgenin on lipid metabolism in rats. J Lipid Res. 1979;162-174.

119. Uchida K, Takase H, Nomura Y, Takeda K, Takeuchi N, Ishikawa Y. Changes in biliary and fecal bile acids in mice after treatments with diosgenin and beta-sitosteroiod. J Lipid Res. 1984;25:236-45.

120. Accatino L, Pizarro M, Solis N, Koeing CS. Effects of diosgenin, a plant derived steroid, on bile secretion and hepatocellular cholestasis induced by estrogen in rats. Hepatology. 1998;28:129-40.

121. Kamisako T, Ogawa H. Regulation of biliary cholesterol secretion is associated with abeg5 and abdg8 expressions in the rats: effects of diosgenin and ethinyl estradiol. Hepatol Res. 2003;26:348-52.

122. Nappez C, Liagre B, Beneytout JL. Changes in lipoxygenase activities in human erythroleukemia (HEL) cells during diosgenin-induced differentiation. Cancer Lett. 1995;96:133-40.
123. Moalic S, Liargre B, Corbiere C, Bianchi A, Dauca M, Bordji K. A plant steroid, diosgenin, induces apoptosis, cell cycle arrest and COX activity in osteosarcoma cells. FEBS Lett. 2001;506:225-30.

124. Neurath MF, Pettersson S, Meyer zum Buschenfelde KH, Strober W. Local administration of antisense phosphorothioate oligonucleotides to the p65 subunit of NF-kappa B abrogates established experimental colitis in mice. Nat Med. 1996:2:998-1004.

125. Owoade AO, Alausa AO, Adetutu A, Olorunnisola OS, Owoade AW. Phytochemical characterization and antioxidant bioactivity of Andrographis paniculate (nees). Pan Afr J Life Sci. 2021;5(2):246-56. https://doi. org/10.36108/pajols/1202.50.0220.

126. Alausa A, Ogundepo S, Olaleke B, Adeyemi R, Olatinwo M, Ismail A. Chinese nutraceuticals and physical activity; their role in neurodegenerative tauopathies. Chin Med. 2021;16(1):1. https://doi.org/10.1186/ s13020-020-00418-7.

127. Aggarwal BB. Nuclear factor-kappa B; the enemy within. Cancer Cell. 2004;6(3):203-8.

128. Bharti AC, Takada Y, Shishodia S, Aggarwal BB. J Biol Chem. 2004;279:6065-76.

129. Auphan N, DiDonato JA, Rosette C, Helmberg A, Karin M. Immunosuppression by glucocorticoids: inhibition of NF-kappa B activity through induction of I kappa B synthesis. Science. 1995;270:286-90.

130. Majumdar S, Aggarwal BB. Methotrexate suppresses NF-kappaB activation through inhibition of IkappaBalpha phosphorylation and degradation. J Immunol. 2001;167:2911-20.

131. Weber CK, Liptay S, Wirth T, Adler G, Schmid RM. Suppression of NF-kappaB activity by sulfasalazine is mediated by direct inhibition of IkappaB kinases alpha and beta. Gastroenterology. 2000;119:1209-18.

132. Guidi L, Costanzo M, Ciarniello M, De Vitis I, Pioli C, Gatta L, et al. Increased levels of NF-kappaB inhibitors (IkappaBalpha and IkappaBgamma) in the intestinal mucosa of Crohn's disease patients during infliximab treatment. Int J Immunopathol Pharmacol. 2005;18:155-64.

133. Ogochukwu Jennifer Umezinwa, Muhammad Alfa Maali, Mohammed Yakubu Manbe, Ugwu Obiora Celestine, Nwankwo Ukechi Joy, Augustine Odibo, and Abdullahi Alausa. Promiscuous Bioactivity of Phytochemicals; AJBGMB 2021; 8 (3); 28-44. Article No: AJBGMB 68583. https://doi.org/10.9734/AJBGMB/2021/v8i330195.

134. Eunice AA, Samuel FO, Alausa A, Zabdiel AA, Adewale B, Sarah AT, Banjo $S$, Ifeoluwa AP. Computational prediction of nimbanal as potential antagonist of respiratory syndrome coronavirus. Informatics in Medicine Unlocked. 2021;24:100617.

135. Neurath MF. Cytokines in inflammatory bowel disease [research support, non-U S Gov't review]. Nat Rev Immunol. 2014;14(5):329-42.

136. Guan Q. A comprehensive review and update on the pathogenesis of inflammatory bowel disease. J Immunol Res. 2019;2019:7247238.

137. Lee SH, Kwon JE, Cho M-L. Immunological pathogenesis of inflammatory bowel disease. Intest Res. 2018;16(1):26-42.

138. Luo X, Yu Z, Deng C, et al. Baicalein ameliorates TNBS-induced colitis by suppressing TLR4/MyD88 signaling cascade and NLRP3 inflammasome activation in mice. Sci Rep. 2017;7(1):16374.

139. Suzuki R, Katakura K, Fujiwara T, et al. Imiquimod induced CCR9 ameliorates murine TNBS colitis. Fukushima J Med Sci. 2016;62(2):90-100.

140. Antoniou E, Margonis GA, Angelou A, Pikouli A, Argiri P, Karavokyros I, Papalois A, Pikoulis E. The TNBS-induced colitis animal model: An overview. Ann Med Surg (2012). 2016;11:9-15. https://doi.org/10.1016/j. amsu.2016.07.019.

141. Visnagri A, Kandhare AD, Kumar VS, et al. Elucidation of ameliorative effect of co enzyme Q10 in streptozotocin-induced diabetic neuropathic perturbation by modulation of electrophysiological, biochemical and behavioral markers. Biomed Aging Pathol. 2012;2(4):157-72.

142. Yin $H$, Bodhankar S, Zhang $G$, et al. Ameliorative effect of morin, a plant flavonoid against Freund's complete adjuvant-induced polyarthritis in rats original article. Pharmacogn Mag. 2019;15(60):43.

143. Kandhare AD, Ghosh $P$, Ghule AE, et al. Elucidation of molecular mechanism involved in neuroprotective effect of coenzyme Q10 in alcoholinduced neuropathic pain. Fundam Clin Pharmacol. 2013;27(6):603-22.

144. Kruidenier L, Kuiper I, Van Duijn W, et al. Imbalanced secondary mucosal antioxidant response in inflammatory bowel disease research support, non-U.S. Gov't. J Pathol. 2003;2011:17-27. 
145. Kruidenier L, Verspaget HW. Oxidative stress as a pathogenic factor in inflammatory bowel disease - radicals or ridiculous? Review Aliment Pharmacol Ther. 2002;16(12):1997-2015.

146. Wang H-W, Liu H-J, Cao H, et al. Diosgenin protects rats from myocardia inflammatory injury induced by ischemia-reperfusion. Med Sci Monit. 2018;12(24):246-53.

147. Patil MVK, Kandhare AD, Bhise SD. Antiinflammatory effect of Daucus carota root on experimental colitis in rats. Int J Pharm Pharm Sci. 2012:4(1):337-43.

148. Adil M, Kandhare AD, Ghosh P, et al. Ameliorative effect of naringin in acetaminophen-induced hepatic and renal toxicity in laboratory rats: role of FXR and KIM-1. Ren Fail. 2016;38(6):1007-20.

149. Ghule AE, Kandhare AD, Jadhav SS, et al. Omega-3-fatty acid adds to the protective effect of flax lignan concentrate in pressure overloadinduced myocardial hypertrophy in rats via modulation of oxidative stress and apoptosis. Int Immunopharmacol. 2015:28(1):751-63.

150. Goswami S, Kandhare A, Zanwar AA, et al. Oral L-glutamine administration attenuated cutaneous wound healing in Wistar rats. Int Wound J. 2016;13(1):116-24.

151. Honmore V, Kandhare A, Zanwar AA, et al. Artemisia pallens alleviates acetaminophen induced toxicity via modulation of endogenous biomarkers. Pharm Biol. 2015;53(4):571-81.

152. Grivennikov S, Karin E, Terzic J, et al. IL-6 and Stat3 are required for survival of intestinal epithelial cells and development of colitis-associated cancer research support, $\mathrm{N} I \mathrm{H}$, extramural research support, Non-U S Gov't. Cancer Cell. 2009;15(2):103-13.

153. Shishodia S, Aggarwal BB. Diosgenin inhibits osteoclastogenesis, invasion, and proliferation through the downregulation of Akt, I KB kinase activation and NF- KB-regulated gene expression. Oncogene. 2006;25(10):1463-73.

154. Cui J, Wang G, Kandhare AD, et al. Neuroprotective effect of naringin, a flavone glycoside in quinolinic acid-induced neurotoxicity: possible role of PPAR- $\gamma$, Bax/Bcl-2, and caspase-3. Food Chem Toxicol. 2018;121:95-108.

155. Guo G, Shi F, Zhu J, et al. Piperine, a functional food alkaloid, exhibits inhibitory potential against TNBSinduced colitis via the inhibition of IKB-a/NF-kB and induces tight junction protein (claudin-1, occludin and ZO-1) signaling pathway in experimental mice. Exp Toxicol. 2020;39(4):477-91.

156. Tang $X$, Huang G, Zhang T, Li S. Elucidation of colon-protective efficacy of diosgenin in experimental TNBS-induced colitis: inhibition of NF-KB/ IkB-a and Bax/Caspase-1 signaling pathways. Biosci Biotechnol Biochem. 2020. https://doi.org/10.1080/09168451.2020.1776590.

157. Raju J, Patlolla JM, Swamy MV, et al. Diosgenin, a steroid saponin of Trigonella foenum graecum (fenugreek), inhibits azoxymethaneinduced aberrant crypt foci formation in F344 rats and induces apoptosis in HT-29 human colon cancer cells. Cancer Epidemiol Biomark Prev. 2004;13(8):1392-8.

158. Ondeykal JG, Herath KB, Jayasuriya H, Polishook JD, Bills GF, Dombrowski AW, et al. Discovery of structurally diverse natural product antagonists of chemokine receptor CXCR3. Mol Divers. 2005;9:123-9.

159. Liu MJ, Wang Z, Ju Y, Wong RN, Wu QY. Diosgenin induces cell cycle arrest and apoptosis in human leukemia K562 cells with the disruption of Ca2+ homeostasis. Cancer Chemother Pharmacol. 2005;55:79-90.

160. Corbiere C, Liagre B, Terro F, Beneytout JL. Induction of antiproliferative effect by diosgenin through activation of $\mathrm{p} 53$, release of apoptosisinducing factor (AIF) and modulation of caspase-3 activity in different human cancer cells. Cell Res. 2004;14:188-96.

161. Costantino L, Barlocco D. STAT3 as a target for cancer drug discovery. Curr Med Chem. 2008;15:834-43.

162. Aggarwal BB, Kunnumakkara AB, Harikumar KB, Gupta SR, Tharakan ST, Koca $C$, et al. Signal transducer and activator of transcription-3, inflammation, and cancer: how intimate is the relationship? Ann N Y Acad Sci. 2009:1171:59-76.

163. Santer FR, Malinowska K, Culig Z, et al. Interleukin- 6 trans-signalling differentially regulates proliferation, migration, adhesion and maspin expression in human prostate cancer cells. Endocr Relat Cancer. 2010;17:241-53.

164. Li Y, Deuring J, Peppelenbosch MP, et al. IL6-induced DNMT1 activity mediates SOCS3 promoter hypermethylation in ulcerative colitisrelated colorectal cancer. Carcinogenesis. 2012;33:1889-96.
165. Mizoguchi E, Xavier RJ, Reinecker HC, et al. Colonic epithelial functional phenotype varies with type and phase of experimental colitis. Gastroenterology. 2003;125:148-61.

166. Greenhalgh CJ, Miller ME, Hilton DJ, et al. Suppressors of cytokine signaling: relevance to gastrointestinal function and disease. Gastroenterol. 2002;123:2064e81.

167. Matsumoto S, Hara T, Mitsuyama K, et al. Essential roles of IL-6 transsignaling in colonic epithelial cells, induced by the IL-6/soluble-IL-6 receptor derived from lamina propria macrophages, on the development of colitis-associated premalignant cancer in a murine model. J Immunol. 2010;184:1543-51.

168. Yang H, Qi H, Ren J, Cui J, Li Z, Waldum HL, Cui G. Involvement of NF- K $\mathrm{B} / \mathrm{LL}-6$ pathway in the processing of colorectal carcinogenesis in colitis mice. Int J Inflamm. 2014;2014. https://doi.org/10.1155/2014/130981.

169. Harpel K, Leung S, Rice PF, et al. Imaging colon cancer development in mice: IL- 6 deficiency prevents adenoma in azoxymethane-treated Smad3 knockouts. Phys Med Biol. 2016;61:N60-9 [25] P. Hruz, S.M. Dann L. Eckmann, STAT3.

170. Garcia R, Bowman TL, Niu G, Yu H, Minton S, Muro-Cacho CA, et al. Constitutive activation of Stat3 by the Src and JAK tyrosine kinases participates in growth regulation of human breast carcinoma cells. Oncogene. 2001;20:2499-513.

171. Campbell GS, Yu CL, Jove R, Carter-Su C. Constitutive activation of JAK1 in Src-transformed cells. J Biol Chem. 1997:272:2591-4.

172. Li F, Fernandez PP, Rajendran P, Hui KM, Sethi G. Diosgenin, a steroidal saponin, inhibits STAT3 signaling pathway leading to suppression of proliferation and chemosensitization of human hepatocellular carcinoma cells. Cancer Lett. 2010;292:197-207.

173. Ihle JN. STATs: signal transducers and activators of transcription. Cell. 1996;84:331-4

174. Chen RH, Chang MC, Su YH, Tsai YT, Kuo ML. Interleukin-6 inhibits transforming growth factor-beta-induced apoptosis through the phosphatidylinositol 3-kinase/Akt and signal transducers and activators of transcription 3 pathways. J Biol Chem. 1999;274:23013-9.

175. Lee H, Herrmann A, Deng JH, Kujawski M, Niu G, Li Z, et al. Persistently activated Stat3 maintains constitutive NF-kappaB activity in tumors. Cancer Cell. 2009;15:283-93.

176. Tenev T, Bohmer SA, Kaufmann R, Frese S, Bittorf T, Beckers T, et al. Perinuclear localization of the protein-tyrosine phosphatase SHP-1 and inhibition of epidermal growth factorstimulated STAT 1/3 activation in A431 cells. Eur J Cell Biol. 2000;79:261-71.

177. Kim H, Baumann H. Dual signaling role of the protein tyrosine phosphatase SHP-2 in regulating expression of acute-phase plasma proteins by interleukin-6 cytokine receptors in hepatic cells. Mol Cell Biol. 1999;19:5326-38.

178. Ohtani T, Ishihara K, Atsumi T, Nishida K, Kaneko Y, Miyata T, et al. Dissection of signaling cascades through gp130 in vivo: reciprocal roles for STAT3- and SHP2-mediated signals in immune responses. Immunity. 2000;12:95-105

179. Servidei T, Aoki Y, Lewis SE, Symes A, Fink JS, Reeves SA. Coordinate regulation of STAT signaling and c-fos expression by the tyrosine phosphatase SHP-2. J Biol Chem. 1998;273:6233-41.

\section{Publisher's Note}

Springer Nature remains neutral with regard to jurisdictional claims in published maps and institutional affiliations. 